\title{
Fruit Size and Yield of Mandarins as Influenced by Spray Volume and Surfactant Use in NAA Thinning
}

\author{
Ed Stover ${ }^{1,2}$, Scott Ciliento, Monty Myers, and Brian Boman \\ University of Florida, Indian River Research and Education Center, 2199 \\ South Rock Road, Ft. Pierce, FL 34945-3138
}

John Jackson, Jr.

University of Florida, Lake County Cooperative Extension, 30205 SR 19, Tavares, FL 32778-0220

\section{Max Still}

University of Florida, Highlands County Cooperative Extension, 4509 West George Blvd., Sebring, FL 33872

Additional index words. Citrus reticulata, cropload, fruit size, naphthaleneacetic acid, organosilicone

Abstract. Six trials were conducted to determine whether lower spray volumes or inclusion of different surfactants would permit adequate thinning of mandarin hybrids (Citrus reticulata hybrids) at a much lower cost per hectare. Sprays were applied using a commercial airblast orchard sprayer during physiological drop when fruitlets averaged 8 to $16 \mathrm{~mm}$ in diameter. Surfactant was always included at $0.05 \% \mathrm{v} / \mathrm{v}$. NAA always reduced fruit per tree, increased fruit size, and decreased production of smallest size fruit. However, in only three experiments, contrast of all NAA treatments vs. controls indicated increased production of the largest (80-100 fruit per carton) and most valuable fruit. In four of five experiments, comparison of spray volumes of 600 (only examined in three of four experiments), 1200 , or $2300 \mathrm{~L} \cdot \mathrm{ha}^{-1}$ demonstrated significant fruit size enhancement from all NAA applications. Most individual NAA treatments resulted in fewer fruit per tree, but there were no statistically significant differences between NAA treatments at different spray volumes. In only one of the four experiments, there was a marked linear relationship between spray volume and fruit per tree, yield, mean fruit size, and production of largest fruit sizes. The effects of surfactants (Activator, a nonionic, Silwet L-77, and LI-700) on NAA thinning were tested in both 'Murcott' and 'Sunburst'. In comparisons between Silwet L-77 and Activator surfactant, one experiment with 'Murcott' showed greater fruit per tree and yield reduction from using Silwet, but with a smaller increase in production of largest fruit sizes, whereas in another 'Murcott' experiment, Silwet L-77 reduced numbers of smaller fruit size with no increase in production of larger fruit. Based on these findings, current recommendations for NAA thinning of Fla. mandarins are use of spray volume of $\approx 1100-1400 \mathrm{~L} \cdot \mathrm{ha}^{-1}$ on mature trees with proportionally lower volume on smaller trees. These data appear to support use of a nonionic surfactant rather than other tested surfactants in NAA thinning of Florida mandarins. Because experience with NAA thinning of Florida citrus is limited, it is only recommended where the disadvantages of overcropping are perceived to substantially outweigh the potential losses from overthinning.

Some citrus cultivars are prone to alternate bearing, in which trees produce very heavy crops of small fruit in the "on" year and much smaller crops of larger fruit in the "off" year (Monselise and Goldschmidt, 1982). This often reduces cumulative fruit value, because many "on"-year fruit may have much lower or even no market value, and production may be so low in the "off"

Received for publication 24 Mar. 2006. Accepted for publication 16 May 2006. Florida Agricultural Experiment Station Journal Series No. R-10204.

${ }^{1}$ Current address: USDA ARS NCGR, One Shields Avenue, Davis, CA 95616.

${ }^{2}$ To whom reprint requests should be addressed; e-mailewstover@ucdavis.edu. year that net commercial production is compromised. Heavy "on"-year production trees may also result in substantial tree stress, reducing growth or breaking limbs, which may adversely affect future production.

Florida citrus producers have primarily relied on hedging, topping, or skirting to reduce cropping in orchards with excessive bearing (Stover et al., 2003), but increased production of larger fruit is often modest or negligible despite substantial cropload reductions (Hilgeman et al., 1964; Monselise and Zaphris, 1960; Morales and Davies, 2000; Stover et al., 2002a, 2003). In addition, pruning for cropload reduction is likely to delay canopy development in young orchards (Stover et al., 2002a). Use of 1-naphthaleneacetic acid (NAA) during early fruit devel- opment has been reported to reduce cropload and increase fruit size for various citrus cultivars in diverse growing regions (Brar et al., 1992; Farmahan, 1992; Gallasch, 1988; Greenberg et al., 1992; Hield et al., 1962; Iwahori, 1978; Ortolá et al., 1991; Sharma et al., 1993; Wheaton, 1981). Although NAA has been labeled for thinning of many Florida citrus varieties for more than 20 years, it has received little commercial use. Published reports on citrus thinning typically involved high spray volumes $\left(2300-4600 \mathrm{~L} \cdot \mathrm{ha}^{-1}\right)$. At rates of 250 to $500 \mathrm{ppm}$ NAA reported to thin Florida citrus, NAA sprays at these volumes would cost US $\$ 400$ per 1600 ha for NAA alone at 2004 prices. Because annual spray material costs for fresh Florida citrus currently average US $\$ 500 /$ ha (Stover et al., 2002 b), high cost is likely to be a major limitation to more widespread NAA thinning of Florida citrus. We conducted six trials to determine whether lower spray volumes or inclusion of different surfactants would permit adequate thinning at much lower cost per hectare.

\section{Materials and Methods}

Trees used in this study

The characteristics of orchards used in this study are listed in Table 1. All experiments were conducted using a randomized complete-block design. Except for orchards one and two, where two-tree experimental units were used (with data taken on individual trees), single trees were used as experimental units and six to eight trees were used per treatment in each orchard. Unsprayed buffer trees were used between all treated trees. All trees were microsprinkler irrigated and received routine care for commercial production of fresh Florida mandarins.

\section{NAA applications}

Treatments were applied during early physiological drop when mean fruitlet diameter was 8 to $16 \mathrm{~mm}$. NAA was applied at 250 or 500 ppm NAA (Fruitfix K-Salt 200; AmVac Chemicals, Long Beach, Calif.) plus $0.05 \%$ surfactant (Activator $^{\mathrm{TM}}$ a nonionic $80 \%$ alkylarylpolyoxyethylene glycols-isopropanol, Diamond-R, Lakeland, Fla.; Silwet L-77 and LI-700, Loveland Industries, Greeley, Colo.), using an airblast sprayer (Rear's Mfg. Co., Eugene, Ore.) at 560-2340 L.ha ${ }^{-1}$ as indicated. Spray volumes were adjusted by changing nozzle size and adjusting travel speed (but never exceeding $4 \mathrm{~km} \cdot \mathrm{h}^{-1}$ ). Sprays were made during periods of negligible wind and good spray coverage was apparent with no spray runoff observed.

\section{Harvest data}

At commercial maturity, trees were stripharvested and all fruit were passed through an optical sorter (Autoline, Reedley, Calif.), mounted on a trailer. The number of fruit per tree and diameter was determined for all fruit, recording all data separately for each tree. Weight and diameter were determined for each fruit in a 30-50 fruit subsample, and the 


\begin{tabular}{|c|c|c|c|c|c|c|c|c|c|c|c|}
\hline \multirow[b]{2}{*}{ Orchard } & \multirow[b]{2}{*}{ Cultivar } & \multirow[b]{2}{*}{ Location } & \multirow[b]{2}{*}{ Rootstock $^{z}$} & \multirow[b]{2}{*}{$\begin{array}{c}\text { Year } \\
\text { planted }\end{array}$} & \multirow[b]{2}{*}{$\begin{array}{l}\text { Spacing } \\
\text { (m) }\end{array}$} & \multirow[b]{2}{*}{$\begin{array}{l}\text { Soil } \\
\text { type }^{y}\end{array}$} & \multicolumn{4}{|c|}{ NAA application parameters } & \multirow[b]{2}{*}{$\begin{array}{c}\text { Harvest } \\
\text { date }\end{array}$} \\
\hline & & & & & & & Date & $\begin{array}{c}\text { Fruitlet } \\
\text { diam } \\
(\mathrm{mm})\end{array}$ & $\begin{array}{l}\text { High } \\
\text { temp } \\
\left({ }^{\circ} \mathrm{C}\right)\end{array}$ & $\begin{array}{c}\text { Estimated } \\
\text { Volume Full } \\
\text { dilute spray } \\
\left(\mathrm{L} \cdot \mathrm{ha}^{-1}\right)^{\mathrm{x}}\end{array}$ & \\
\hline 2 & Sunburst & Howey-in-the-Hills & Sour orange & 1988 & $9.24 \times 1.54$ & Apopka & 1 June 1998 & $16.4(39 \%<15)$ & 33.3 & 7000 & 18 Nov 1998 \\
\hline 3 & Murcott & Palm City & Cleopatra & 1993 & $6.86 \times 3.05$ & Waveland & 18 May 1998 & $9.3(99 \%<15)$ & 28.2 & 5000 & 9 Mar 1999 \\
\hline 4 & Murcott & Palm City & Cleopatra & 1993 & $6.86 \times 3.05$ & Waveland & 23 May 1999 & $8.3(100 \%<15)$ & 27.9 & 5000 & 28 Feb 2000 \\
\hline
\end{tabular}

${ }^{\mathrm{z}}$ Cleopatra $=$ Cleopatra mandarin, Citrus reticulata; Sour orange $=$ Citrus aurantium.

y Predominant soil type in each experimental orchard is listed, but inclusions of related soil types were present in all orchards. All soil types listed are fine sand soils, but Waveland and Boca include hardpans close to the surface and require bedding to achieve drainage adequate for commercial citrus production.

${ }^{x}$ Volume estimates for full dilute spray of $10,000 \mathrm{~L} \cdot \mathrm{ha}^{-1}$ for a citrus orchard of mature canopy $4.6 \mathrm{~m}$ in height.

calculated regression in each trial $\left(r^{2}\right.$ for these regressions ranged from 0.93 to 0.98 ) was used to convert diameter data to weight estimates. No data were collected on Brix, titratable acidity, or fruit color since no effects were observed when these data were collected in earlier experiments (data not shown).

\section{Statistical analysis}

The parameters analyzed for each tree were: number of fruit per tree, weight of fruit per tree, mean fruit weight, and cartons of fruit $(28.2 \mathrm{~L}$ per carton, $\approx 21.6 \mathrm{~kg})$ in economic size classes. Data were analyzed using the GLM procedure of SAS (SAS Institute, Cary, N.C.); mean separation was determined using Duncan's multiple range test (DMRT) at $P \leq 0.05$ and contrast analyses were conducted.

\section{Results and Discussion}

\section{Comparing NAA treatments vs.} nontreated controls

In contrast analyses of all NAA treatments vs. nonthinned controls, NAA thinning treatments decreased fruit number per tree and increased mean fruit size compared with nonthinned controls in all six experiments (Tables 2-7). However, using DMRT for mean separation, several individual treat- ments were not significantly different from the controls in two of the six experiments, both with 'Sunburst' (Tables 2 and 7). Considering all experiments, NAA treatment reduced fruit number per tree from $73 \%$ (Table 6) to as little as $12 \%$ (not significant; Table 7) compared with nonthinned controls. Mean fruit size increase in NAA-treated trees ranged from $8 \%$ (not significant; Table 6 ) to as much as $39 \%$ (Table 2).

In four of the experiments, contrast analyses of all NAA treatments vs. controls showed a significant reduction in $\mathrm{kg}$ of fruit per tree (Tables 3-6). Interestingly, the experiment in orchard 1 (Table 2), which displayed among the largest fruit size increases, was one of two experiments with no significant reduction in yield after NAA thinning. In this experiment, yield was numerically reduced by $4 \%$ to $14 \%$ when NAA treated trees were compared with nontreated controls. This was also the only orchard in this report in which nonthinned trees were clearly overcropped with some breakage of limbs through excessive fruit weight, and yet no breakage was observed on thinned trees (data not shown). The other experiment in which yield reduction was not significant after NAA thinning was in orchard 6 (Table 7 ), in which cropload (fruit per tree) reductions of $12 \%$ to $30 \%$ resulted in $9 \%$ to $16 \%$ increases in mean fruit weight. The two experiments with no cropload reduction were also the only experiments in which controls had high percentages of unmarketable small fruit (Tables 2 and 7).

Effect of NAA treatments on production of different fruit sizes varied widely among the six experiments. In three of the six experiments, contrast of all NAA treatments vs. controls showed a significant increase in production of fruit in the largest sizes classes (size 80-100, meaning 80-100 fruit are required to fill a 21.6-kg carton). In one additional experiment, the contrast $P$ value was 0.09 (Table 3 ) for increase in production of size 80 to 100 fruit. All six experiments showed numeric increases in production of size 80 to 100 fruit, ranging from $29 \%$ (not significant; Tables 6 and 7) to 71\% (Table 2) more than the respective nonthinned control in each experiment. In all six experiments, NAA induced reductions in cartons of the smallest fruit sizes (210 fruit per $21.6-\mathrm{kg}$ carton or smaller size), and in five of six experiments (Tables 2-6), the reduction extended to medium-sized fruit (150 fruit per 21.6-kg carton). Contrast between nonthinned controls and all NAA treatments showed an increase of production in size 80 to $120(36 \%$ increase $)$ and size 80 to $150(17 \%$ increase) fruit in one experiment (Table 2),

Table 2. Effect of spray volume and surfactant on cropping parameters of 'Sunburst'/Cleopatra mandarin at different spray volumes and with different surfactant after NAA thinning: Sebring, Fla. 1997. All NAA applications were at $500 \mathrm{ppm}$ in spray solution. All surfactants (nonionic was Diamond-R Activator $80 \%$ alkylarylpolyoxyethylene glycols-isopropanol, Diamond-R, Lakeland, Fla.; Silwet L-77, Greeley, Colo.) were used at 0.5\% (v/v).

\begin{tabular}{|c|c|c|c|c|c|c|c|c|c|c|c|c|c|c|}
\hline & \multirow[b]{2}{*}{ Treatment } & \multirow{2}{*}{$\begin{array}{l}\text { Fruit per } \\
\text { tree }\end{array}$} & \multirow{2}{*}{$\begin{array}{c}\text { Fruit } \\
\text { size }(g)\end{array}$} & \multirow{2}{*}{$\begin{array}{l}\text { Yield/ } \\
\text { tree }(\mathrm{kg})\end{array}$} & \multicolumn{10}{|c|}{ Cartons $^{y}$ per tree at indicated fruit sizes by numbers of fruit/carton } \\
\hline & & & & & Smaller & $210 \mathrm{~s}$ & $176 \mathrm{~s}$ & $150 \mathrm{~s}$ & $120 \mathrm{~s}$ & $100 \mathrm{~s}$ & $80 \mathrm{~s}$ & $80-150$ & $80-120$ & $80-100$ \\
\hline 2 & Nonionic, $610 \mathrm{~L} \cdot \mathrm{ha}^{-1}$ & $1626 \mathrm{ab}$ & $134 \mathrm{c}$ & $212 \mathrm{a}$ & $1.44 \mathrm{~b}$ & $0.46 \mathrm{~b}$ & $1.51 \mathrm{ab}$ & $1.71 \mathrm{ab}$ & $3.53 \mathrm{a}$ & $1.57 \mathrm{bc}$ & $0.83 \mathrm{~b}$ & $7.6 \mathrm{a}$ & $5.9 \mathrm{ab}$ & $2.4 \mathrm{bc}$ \\
\hline \multirow[t]{3}{*}{5} & $\begin{array}{l}\text { Silwet L-77, } 610 \mathrm{~L} \cdot \mathrm{ha}^{-1} \\
\text { Contrast analyses }\end{array}$ & $1358 \mathrm{~b}$ & $144 \mathrm{bc}$ & $193 \mathrm{a}$ & $0.80 \mathrm{~b}$ & $0.34 \mathrm{bc}$ & $1.05 \mathrm{bc}$ & $1.53 \mathrm{a}-\mathrm{c}$ & $3.47 \mathrm{a}$ & $1.85 \mathrm{~b}$ & $0.90 \mathrm{ab}$ & $7.8 \mathrm{a}$ & $6.2 \mathrm{ab}$ & $2.8 \mathrm{bc}$ \\
\hline & $\begin{array}{l}\text { All NAA vs. control } \\
(1 \text { vs. } 2,3,4 \text {, and } 5)\end{array}$ & 041 & 0.0001 & 0.1842 & 0.0006 & 0.0003 & 0.0014 & 0.0057 & 0.0884 & 0.0004 & 0.1038 & 0.0785 & 0.007 & 0.0044 \\
\hline & $\begin{array}{l}1170 \mathrm{~L} \cdot \mathrm{ha}^{-1} \text { vs. } 2340 \mathrm{~L} \cdot \mathrm{ha}^{-1} \\
(3 \text { vs. } 4 \text { ) }\end{array}$ & 0.6632 & 0.099 & 0.7926 & 0.9563 & 0.4356 & 0.2999 & 0.0886 & 0.1292 & 0.0716 & 0.0915 & 0.9939 & 0.572 & 0.0644 \\
\hline & $\begin{array}{l}\text { Nonionic vs. Silwet } \\
(2 \text { vs. } 5)\end{array}$ & 0.2034 & 0.1121 & 0.3859 & 0.2147 & 0.2212 & 0.0554 & 0.4139 & 0.8534 & 0.2652 & 0.7556 & 0.8798 & 0.6685 & 0.4454 \\
\hline
\end{tabular}

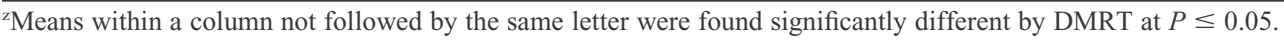

y $28.2 \mathrm{~L}$ per carton estimated at $21.6 \mathrm{~kg}$. 
Table 3. Effect of spray volume and NAA concentration on cropping parameters of 'Sunburst'/Sour Orange after NAA thinning: Howey-in-the-Hills, Fla. 1997. Values for NAA are ppm in spray solution. Nonionic surfactant (Diamond-R Activator $80 \%$ alkylarylpolyoxyethylene glycols-isopropanol, Diamond-R, Lakeland, Fla.) was used at $0.5 \%(\mathrm{v} / \mathrm{v})$ in all sprays.

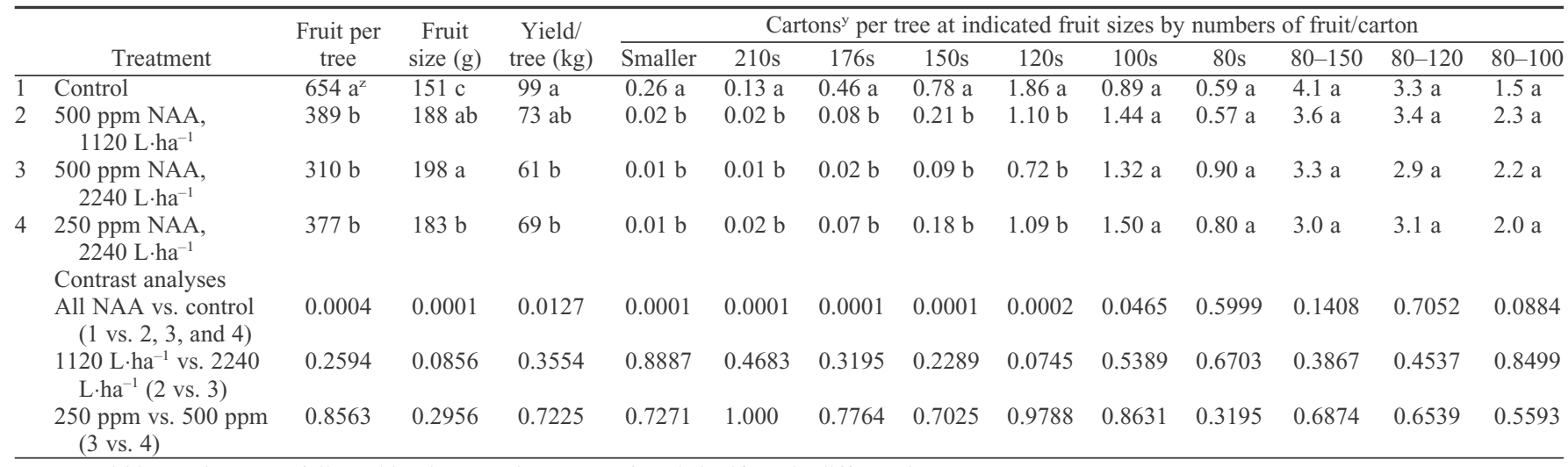

${ }^{\mathrm{z}}$ Means within a column not followed by the same letter were found significantly different by DMRT at $P \leq 0.05$.

y $28.2 \mathrm{~L}$ per carton estimated at $21.6 \mathrm{~kg}$.

Table 4. Effect of surfactant, spray volume, and NAA concentration on cropping parameters of 'Murcott'/Cleopatra mandarin after NAA thinning: Palm City, Fla. 1998-1999. Values for NAA are ppm in spray solution. All surfactants (nonionic was Diamond-R Activator 80\% alkylarylpolyoxyethylene glycols-isopropanol, Diamond-R, Lakeland, Fla.; Silwet L-77, Loveland Industries, Greeley, Colo.) were used at 0.5\% (v/v).

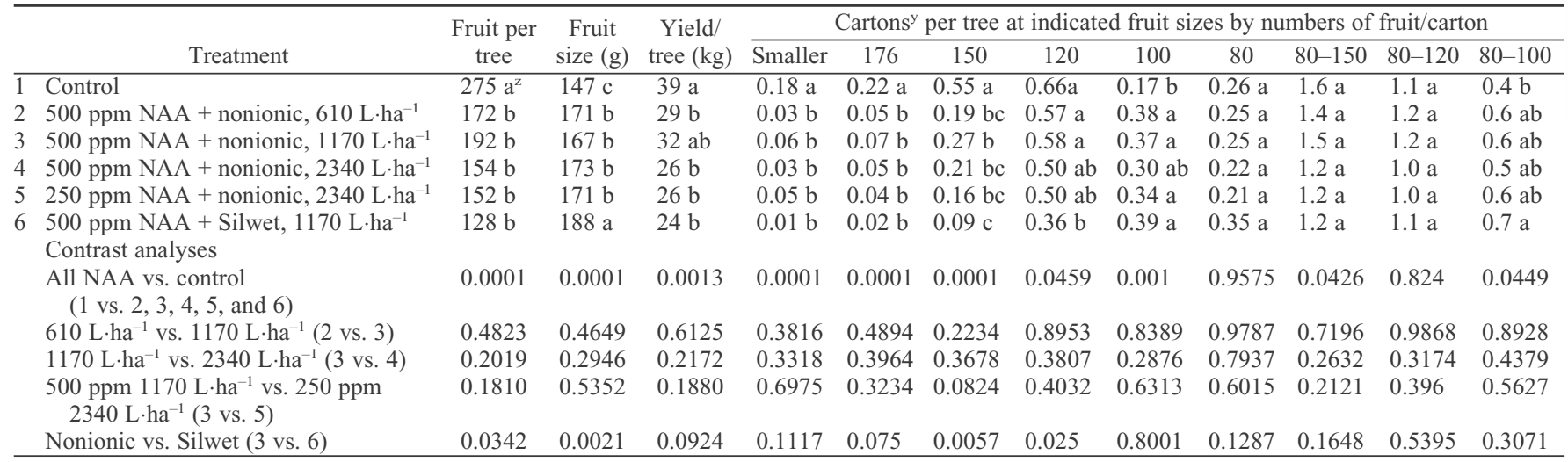

${ }^{\mathrm{z}}$ Means within a column not followed by the same letter were found significantly different by DMRT at $P \leq 0.05$.

y28.2 L per carton estimated at $21.6 \mathrm{~kg}$.

no effect in two experiments (Tables 3 and 7), and significant reductions in cumulative marketable sizes in three experiments (Table 4, size $80-150$ reduced by $20 \%$; Table 5 , size $80-120$ reduced by $25 \%$ and size $80-150$ reduced by $38 \%$; Table 6 , size $80-120$ reduced by $34 \%$ and size $80-150$ reduced by $45 \%$ ). It may be noteworthy that these NAA-induced reductions in production of marketable fruit occurred in the three experiments on 'Murcott', which tend to produce somewhat larger fruit than 'Sunburst'.

\section{Effects of spray volume and NAA rate}

All six experiments included comparisons between treatments in which total NAA applied per hectare was varied through changing spray volume at the same NAA concentration or changing NAA concentration at the same spray volume. DMRT indicated only two experiments in which differences between these treatments were significant at $P \leq 0.05$, despite two- to fourfold differences in the amount of NAA applied per hectare among these treatments. In orchard one 'Sunburst' (Table 2), there was a marked linear increase in cropload reduc- tion and mean fruit size increase as spray volume and associated g NAA applied per hectare increased. In orchard five 'Murcott' (Table 6), doubling NAA use per hectare by using 500 vs. $250 \mathrm{ppm}$ at the same spray volume increased both cropload reduction (from $63 \%$ to $73 \%$ thinning) and mean fruit size (from 178 to $197 \mathrm{~g}$ ), although both treatments were somewhat excessive in cropload reduction. Contrast analyses between NAA treatments suggested an effect of the amount of NAA applied per hectare in only one other experiment: in orchard two 'Sunburst' (Table 3), $1120 \mathrm{~L} \cdot \mathrm{ha}^{-1}$ produced a mean fruit size smaller than $2240 \mathrm{~L} \cdot \mathrm{ha}^{-1}$ ( $188 \mathrm{vs.} 198$ $\mathrm{g})$, but the contrast was only significant at $P=$ 0.09 . Overall, the most remarkable outcome was that in most experiments, substantial reductions in fruit number per tree or increases in mean fruit size occurred even at moderate levels of NAA per hectare using spray volumes of 600 to $1200 \mathrm{~L} \cdot \mathrm{ha}^{-1}$.

\section{Effect of surfactant type}

There were no treatments in which surfactant was not included with NAA, because previous experience in Florida demonstrated the value of including surfactant for NAAthinning of citrus (Adair Wheaton, personal communication, 1996), Florida extension recommendations on NAA thinning recommended inclusion of surfactant (e.g., Davies et al., 1998), and virtually all published NAA thinning trials on citrus noted inclusion of surfactant, whereas none directly tested their influence on NAA thinning. The effect of Activator nonionic vs. Silwet L-77 surfactants on NAA thinning was compared in four experiments and the additional surfactant LI-700 was included in two of these experiments. Inclusion of Silwet L-77 vs. nonionic surfactant in the NAA spray resulted in greater cropload reduction in two of the four experiments $(63 \%$ vs. $46 \%$, Table 4 , significant by contrast analysis but not DMRT; $53 \%$ vs. $30 \%$, Table 6), both in 'Murcott' but in 2 separate years. In 1 year (Table 4), difference in cropload reduction from inclusion of Silwet L-77 vs. nonionic surfactant also translated into a significant increase in mean fruit size (188 g vs. $167 \mathrm{~g}$ ) but not an increase in production of fruit in the size 80 to 100 range. In the next year (Table 6), mean fruit size was numerically lower in the trees 
Table 5. Effect of spray volume and NAA concentration on cropping parameters of 'Murcott'/Cleopatra mandarin after NAA thinning: Palm City, Fla. $1999-2000$. Values for NAA are ppm in spray solution. Silwet L-77 surfactant (Loveland Industries, Greeley, Colo.) was used at $0.5 \%$ (v/v) in all sprays.

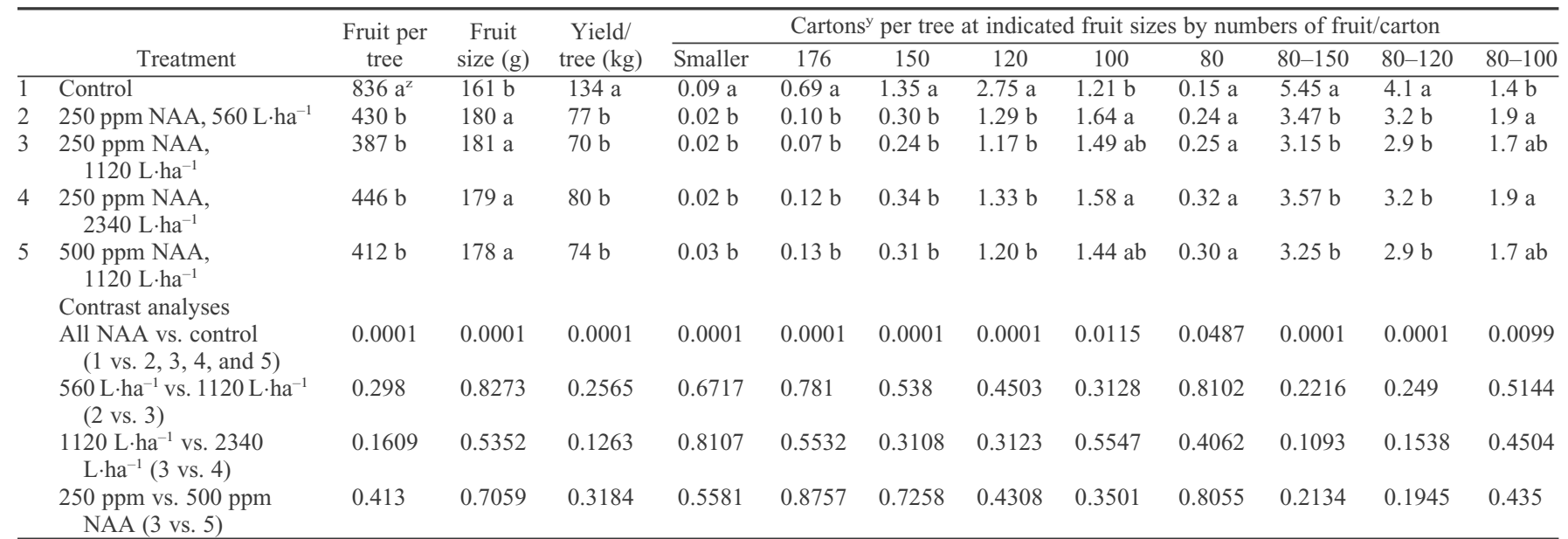

${ }^{2}$ Means within a column not followed by the same letter were found significantly different by DMRT at $P \leq 0.05$.

y28.2 L per carton estimated at $21.6 \mathrm{~kg}$.

Table 6. Effect of surfactant and NAA concentration on cropping parameters of 'Murcott'/Cleopatra mandarin after NAA thinning: Palm City, Fla. 1999-2000. Values for NAA are ppm in spray solution. All surfactants (nonionic was Diamond-R Activator 80\% alkylarylpolyoxyethylene glycols-isopropanol, Diamond-R, Lakeland, Fla.; Silwet L-77 and LI-700, Loveland Industries, Greeley, Colo.) were used at 0.5\% (v/v). All sprays were applied at 1870 L-ha ${ }^{-1}$.

\begin{tabular}{|c|c|c|c|c|c|c|c|c|c|c|c|c|c|}
\hline & \multirow[b]{2}{*}{ Treatment } & \multirow{2}{*}{$\begin{array}{l}\text { Fruit per } \\
\text { tree }\end{array}$} & \multirow{2}{*}{$\begin{array}{c}\text { Fruit } \\
\text { size }(g)\end{array}$} & \multirow{2}{*}{$\begin{array}{l}\text { Yield/ } \\
\text { tree }(\mathrm{kg})\end{array}$} & \multicolumn{9}{|c|}{ Cartons $^{y}$ per tree at indicated fruit sizes by numbers of fruit/carton } \\
\hline & & & & & Smaller & 176 & 150 & 120 & 100 & 80 & $80-150$ & $80-120$ & $80-100$ \\
\hline 2 & $250 \mathrm{ppm}$ NAA+ LI-700 & $486 \mathrm{~b}$ & $173 \mathrm{c}$ & $84 \mathrm{~b}$ & $0.04 \mathrm{~b}$ & $0.21 \mathrm{~b}$ & $0.50 \mathrm{~b}$ & $1.5 \mathrm{~b}$ & $1.44 \mathrm{ab}$ & $0.20 \mathrm{~b}$ & $3.6 \mathrm{~b}$ & $a b$ & $1.6 \mathrm{ab}$ \\
\hline 4 & $250 \mathrm{ppm}$ NAA + Silwet & $1 \mathrm{c}$ & $178 \mathrm{bc}$ & $52 \mathrm{c}$ & $02 \mathrm{~b}$ & $12 \mathrm{bc}$ & $0.21 \mathrm{c}$ & $0.78 \mathrm{~cd}$ & $1.04 \mathrm{bc}$ & $0.24 \mathrm{~b}$ & $2.3 \mathrm{c}$ & & $1.3 \mathrm{~b}$ \\
\hline \multirow[t]{5}{*}{5} & $\begin{array}{l}500 \mathrm{ppm} \text { NAA + Silwet } \\
\text { Contrast analyses }\end{array}$ & $3 \mathrm{~d}$ & $197 \mathrm{a}$ & $42 \mathrm{c}$ & $1 \mathrm{~b}$ & $0.03 \mathrm{c}$ & $0.10 \mathrm{c}$ & $0.37 \mathrm{~d}$ & $0.86 \mathrm{c}$ & $0.57 \mathrm{a}$ & $1.9 \mathrm{c}$ & 1.8 & $1.4 \mathrm{~b}$ \\
\hline & $\begin{array}{l}\text { All NAA vs. control } \\
(1 \text { vs. } 2,3,4 \text {, and } 5)\end{array}$ & 0.0001 & 0.000 & 0.0001 & 0001 & 0.0001 & 0.0001 & 0001 & 0.7255 & 0.0005 & 0.0001 & 0002 & 0.1244 \\
\hline & LI-700 vs. Silwet (2 vs. 4 ) & 0.0016 & 0.2016 & 0.0023 & 2883 & 0.0949 & 0.0035 & 0.0016 & 0.0860 & 0.6554 & 0.0028 & 0.0087 & 0.1966 \\
\hline & & & $v_{2}$ & & & & & & & 0.0177 & & & 0.0038 \\
\hline & LI- 700 vs. nonionic ( 2 vs. 3 ) & 0.3092 & 0.015 & 0.5824 & 0.2883 & 0.0793 & 0.0215 & 0.0480 & 0.2899 & 0.0062 & 0.7541 & 0.8156 & 0.0735 \\
\hline
\end{tabular}

${ }^{2}$ Means within a column not followed by the same letter were found significantly different by DMRT at $P \leq 0.05$.

${ }^{\mathrm{y}} 28.2 \mathrm{~L}$ per carton estimated at $21.6 \mathrm{~kg}$.

Table 7. Effect of surfactant, NAA concentration, and spray volume on cropping parameters of 'Sunburst'/Cleopatra mandarin after NAA thinning: Loxahatchee, Fla. 1999. Values for NAA are ppm in spray solution. All surfactants (nonionic was Diamond-R Activator, 80\% alkylarylpolyoxyethylene glycolsisopropanol, Diamond-R, Lakeland, Fla.; Silwet L-77 and LI-700, Loveland Industries, Greeley, Colo.) were used at 0.5\% (v/v).

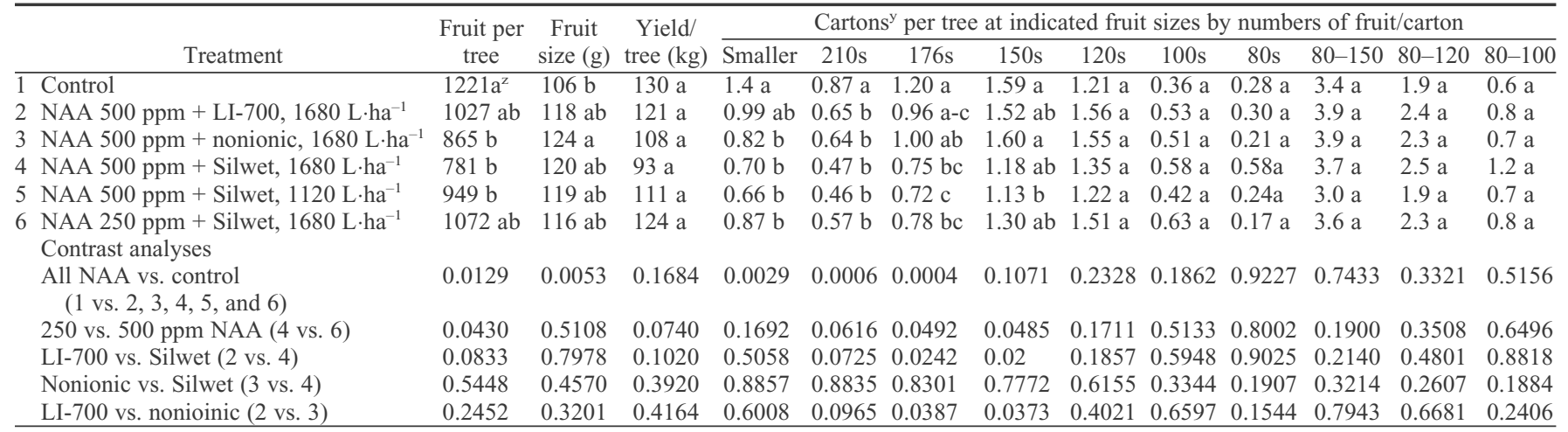

${ }^{2}$ Means within a column not followed by the same letter were found significantly different by DMRT at $P \leq 0.05$.

y $28.2 \mathrm{~L}$ per carton estimated at $21.6 \mathrm{~kg}$.

that included Silwet in the thinning spray, although not statistically significant, but production of larger fruit was significantly reduced (cartons per tree of size 80-100 fruit was 1.3 for Silwet vs. 2.2 for nonionic surfactant). No statistically significant differ- ences were seen between Silwet and nonionic surfactant-containing treatments in the two 'Sunburst' experiments. In the two experiments that included LI-700, inclusion of this surfactant resulted in less NAA thinning than inclusion of Silwet (Tables 6 and 7), although production of the largest fruit sizes was not influenced. Use of nonionic surfactant in the NAA solution resulted in somewhat greater mean fruit size than use of LI-700 in one experiment (183 vs. $173 \mathrm{~g}$; Table 6). 
Practical significance. Based on these findings, current recommendations for NAA thinning of Florida mandarins are use of spray volume of $\approx 1100$ to $1400 \mathrm{~L} \cdot \mathrm{ha}^{-1}$ on mature trees with proportionally lower volume on smaller trees (Stover et al., 2001). It is clear that higher NAA rate per hectare sometimes increases thinning and fruit size enhancement but may also result in excessive thinning. Although cost of NAA application remains high, use of lower rates appears to be a prudent approach.

These data appear to support use of a nonionic surfactant rather than other tested surfactants in NAA thinning of Florida mandarins. Inclusion with NAA of organosilicone surfactant sometimes increased thinning effect and mean fruit size when compared with nonionic surfactant, but the instances in which production of larger fruit sizes was reduced or unaffected despite greater thinning make use of an organosilicone surfactant less attractive. However, it is possible that use of even lower rates of NAA with the organosilicone may give adequate thinning with increased production of larger fruit. Interestingly, there is a recent report that Silwet L-77 transiently suppresses photosynthesis when applied to citrus (Orbovic et al., 2001), and this phenomenon may explain the results reported here.

It has been reported that the greatest benefit of thinning Florida mandarins is often observed the following year from reducing alternate bearing rather than from higher value within the year of thinning (Stover et al., 2002a), so it is unfortunate that return cropping data were not collected for the experiments reported here. Because experience with NAA thinning of Florida citrus is limited, it is only recommended where the disadvantages of overcropping are perceived to substantially outweigh the potential losses from overthinning.

\section{Literature Cited}

Brar, S.S., P.P.S. Minhas, and G.S. Kaundal. 1992. Chemical thinning of 'Kinnow' mandarin. Acta Hort. 321:443-448.

Davies, F.S., M.A. Ismail, E.W. Stover, D.P.H. Tucker, and T.A. Wheaton. 1998. 1998 Florida citrus pest management guide: Plant growth regulators. IFAS Fact Sheet HS-108.

Farmahan, H.L. 1992. Chemical thinning improves "off" year crop harvest in 'Kinnow' mandarin. Hort. J. 5:67-72.

Gallasch, P.T. 1988. Chemical thinning of heavy crops of mandarins to increase fruit size. Proc. 6th Intl. Citrus Congr. 395-405.

Greenberg, J., Y. Hertzano, and G. Eshel. 1992. Effects of 2,4-D, ethephon, and NAA on fruit size and yield of 'Star Ruby' red grapefruit. Proc. Intern. Soc. Citricult. 1:520-523.

Hield, H.Z., R.M. Burns, and C.W. Coggins. 1962. Some fruit thinning effects of naphthalenacetic acid on Wilking mandarin. Proc. Amer. Soc. Hort. Sci. 81:218-222.

Hilgeman, R.H., L. True, and J.A. Dunlap. 1964. Effect of naphthalenacetic acid spray and hand thinning on size of Kinnow mandarin fruit in Arizona. Proc. Fla. State Hort. Soc. 77:84-87.

Iwahori, S. 1978. Use of growth regulators in control of cropping of mandarin varieties. Proc. Intl. Soc. Citricult. 1:263-270.

Monselise, S.P. and E.E. Goldschmidt. 1982. Alternate bearing in fruit trees. Hort. Rev. (Amer Soc Hort Sci) 4:128-173.
Monselise, S.P. and J. Zaphris. 1960. Increasing the size of Clementine mandarin fruits. Hassadeh 40:1359-1362.

Morales, P. and F.S. Davies. 2000. Pruning and skirting affect canopy microclimate, yields and fruit quality of 'Orlando' tangelo. HortScience 35:30-35.

Orbovic, V., J.L. Jifon, and J.M. Syvertsen. 2001. Foliar-applied surfactants and urea temporarily reduce carbon assimilation of grapefruit leaves. J. Amer. Soc. Hort. Sci. 126:486490.

Ortolá, A.G., C. Monerri, and J.L. Guardiola. 1991. The use of naphthalene acetic acid as a fruit growth enhancer in Satsuma mandarin: a comparison with the fruit thinning effect. Scientia Hort. 47:15-25.

Sharma, J.N., K. Nirmaljit, and J.S. Josan. 1993. Crop manipulation in 'Kinnow' mandarin with chemicals. Punjab Hort. J. 33:21-24.

Stover, E., S. Ciliento, and T. Murphy. 2003. Latesummer topping increases fruit size in Indian River 'Murcott'. Proc. Fla. State Hort. Soc. 116:275-278.

Stover, E., S. Ciliento, M. Ritenour, and C. Counter. 2002a. NAA thinning of 'Murcott': comparison of small plot and commercial harvest data. Proc. Fla. State Hort. Soc. 115:287-291.

Stover, E., D. Scotto, and J. Salvatore. 2002b. Pesticide spraying in Indian River grapefruit: I. Survey of current practices. HortTechnology 12:454-460.

Stover, E., A. Wheaton, and G. Albrigo. 2001. Chemical thinning of citrus with NAA for bigger fruit, less branch breakage, and more regular cropping. Extension Fact Sheet HS-800.

Wheaton, T.A. 1981. Fruit thinning of Florida mandarins using plant growth regulators. Proc. Intl. Soc. Citricult. 1:263-268. 